\title{
Uwarunkowania opóźnień w diagnostyce i terapii kobiet chorych na raka piersi w Polsce związane z postawami chorych
}

\author{
Sylwia Grodecka-Gazdecka', Piotr Zaborek' ${ }^{2}$, Joanna Didkowska ${ }^{3}$, \\ Krystyna de Walden-Gałuszko ${ }^{4}$, Paweł Handschuh ${ }^{5}$, Jacek Jassem ${ }^{6}$, Tadeusz Pieńkowski ${ }^{7}$
}

Wstęp. Czas upływający od początku choroby do rozpoczęcia terapii chorych na raka piersi ma wpływ na końcowy efekt leczenia. Opóźnienie w podjęciu leczenia może mieć przyczynę leżącą po stronie pacjenta, lekarza lub systemu opieki zdrowotnej. Czas od zauważenia objawów sugerujących raka piersi do zgłoszenia się do lekarza jest określony jako opóźnienie wynikające z postaw pacjenta. Celem projektu było określenie przyczyn opóźnień w rozpoznaniu raka piersi i podjęciu leczenia u kobiet w Polsce. W niniejszej pracy odniesiono się do przyczyn opóźnienia wynikających z postaw pacjentek.

Materiał i metody. Badanie polegało na przeprowadzeniu ankiety w grupie 1000 chorych na raka piersi, pochodzących z 10 losowo wybranych ośrodków onkologicznych i szpitali z oddziałami onkologicznymi. Ankietę przeprowadzały odpowiednio przeszkolone pielęgniarki zatrudnione w danej placówce, z wykorzystaniem elektronicznego kwestionariusza umieszczonego na przenośnym komputerze typu tablet. Przedmiotem analizy były chore, które same zauważyły objawy sugerujące raka piersi, stanowiące $56 \%$ respondentek (u pozostałych podejrzenie choroby pojawiło się podczas rutynowej kontroli lekarskiej lub badania mammograficznego).

Wyniki. Średni czas opóźnienia wynikającego z postaw pacjentek wynosił 3,6 tygodnia. Był on związany dodatnio z lekceważeniem dostrzeżonych objawów i brakiem zaufania do systemu ochrony zdrowia oraz ujemnie — z poziomem lęku przed konsekwencjami raka piersi i nawykiem samobadania piersi. Lęk był odczuwany silniej przez pacjentki w młodszym wieku ( $R=-0,147 ; p=0,001)$, lepiej wykształcone $(R=0,109 ; p=0,012$ ) oraz te, u których rozpoznanie ustalono w prywatnej placówce ochrony zdrowia $(R=-0,115 ; p=0,008)$. Lekceważenie było silniejsze dla respondentek z niższym wykształceniem $(R=-0,121 ; p=0,005)$, mieszkanek miejscowości $<300$ tys. mieszkańców $(R=-0,116$; $p=0,008)$ oraz starszych kobiet $(R=0,104 ; p=0,016)$. Samobadanie piersi częściej deklarowały kobiety młodsze $(R=-0,121 ; p=0,005)$, lepiej wykształcone $(R=0,156 ; p<0,001)$ oraz te, u których rozpoznanie ustalono w prywatnej placówce ochrony zdrowia $(R=-0,126 ; p=0,004)$. Im niższe było wykształcenie, tym wyższy był deklarowany poziom nieufności wobec systemu opieki medycznej i szans na udane leczenie $(R=-0,191 ; p<0,001)$.

Wnioski. Zgłoszenie się do lekarza jest wynikiem całego ciągu zdarzeń o podłożu psychicznym i społecznym, takich jak dostrzeżenie podejrzanej zmiany, przekonania zdrowotne, poziom wykształcenia, reakcje emocjonalne i więzi społeczne. Działania na rzecz zmniejszenia opóźnienia w podjęciu diagnostyki i leczenia raka piersi w Polsce spowodowanego postawami pacjentek powinny polegać na osłabianiu udziału czynników opóźniających rozpoznanie oraz wzmacnianiu udziału czynników zmniejszających to opóźnienie. Działania te powinny być elementem wielopłaszczyznowej edukacji zdrowotnej.

\footnotetext{
${ }^{1}$ Katedra i Klinika Onkologii, Uniwersytet Medyczny im. Karola Marcinkowskiego w Poznaniu

${ }^{2}$ Szkoła Główna Handlowa w Warszawie

${ }^{3}$ Krajowy Rejestr Nowotworów, Zakład Epidemiologii i Prewencji Nowotworów, Centrum Onkologii — Instytut w Warszawie

${ }^{4}$ Wojewódzkie Centrum Onkologii w Gdańsku

${ }^{5}$ Roche Polska Sp. z o.o., Warszawa

${ }^{6}$ Klinika Onkologii i Radioterapii, Gdański Uniwersytet Medyczny

${ }^{7}$ Klinika Onkologii CMKP, Europejskie Centrum Zdrowia w Otwocku

Praca wykonana na podstawie trójstronnej umowy pomiędzy Polskim Towarzystwem Onkologicznym, Polskim Towarzystwem do Badań nad Rakiem Piersi i firmą Roche Polska Sp. z o.o.
} 


\section{Determinants of delays in diagnosis and treatment of breast cancer among women in Poland resulting from patients' attitudes}

Introduction. Time elapsed between the beginning of the illness and the initiation of treatment in breast cancer patients influences the final outcome of treatment. Delays in administration of treatment may result from factors associated with a patient, a doctor, or the healthcare system. A delay resulting from patients' attitudes is defined as the time between the onset of symptoms indicative of cancer and the first medical consultation. The purpose of this study was to establish the determinants of delays in diagnosis and initiation of treatment among women in Poland. In this article, the authors present the delays resulting from patients' attitudes.

Materials and methods. The study was based on a survey performed by trained nurses on 1,000 breast cancer patients selected from 10 randomly chosen medical institutions. An electronic form for the survey was saved on a tablet computer. The study included patients who themselves noticed breast cancer symptoms: this constituted $56 \%$ of the participants. In the remaining patients suspected signs were found during routine medical examination or at mammography.

Results. The mean time of delay in treatment resulting from patients' attitudes was 3.6 weeks. It was positively correlated with patients' ignoring observed symptoms and a lack of trust in the healthcare system, and negatively correlated with the level of fear of the consequences of breast cancer and practicing of self-examination. Fear was experienced more strongly by younger patients $(R=-0.147 ; p=0.001)$, patients with a higher level of education $(R=$ $0.109 ; p=0.012)$ and patients who were diagnosed in a privately owned institutions $(R=-0.115 ; p=0.008)$. Ignoring symptoms was more common among less educated participants $(R=-0.121 ; p=0.005)$, residents of smaller towns with populations $<300$ thousand inhabitants $(R=-0.116 ; p=0.008)$ and older women $(R=0.104 ; p=0.016)$. The participants who practiced breast self-examinations were usually younger ( $R=-0.121 ; p=0.005)$, better educated $(R=0.156 ; p<0.001)$ and diagnosed in a privately owned institution $(R=-0.126 ; p=0.004)$. The lower the level of education, the higher the indicated level of distrust of the healthcare system and of the chances for successful treatment $(R=-0.191 ; p<0.001)$.

Conclusions. The decision to visit a doctor results from several psychological and social factors, such as noticing suspected symptoms, patient beliefs regarding their health, level of education, emotional reactions and social connections. Activities aimed at reducing delays in diagnosis and treatment of breast cancer in Poland related to patients attitudes should focus on reducing the impact of factors delaying treatment and on increasing the impact of factors shortening these delays. Such activities should be part of a multilevel health education program.

NOWOTWORY Journal of Oncology 2013; 63, 4: 286-294

Słowa kluczowe: rak piersi, opóźnienie leczenia, aspekty psychologiczne

Key words: breast cancer, delay in treatment, psychological factors

\section{Wstęp}

Rak piersi jest największym problemem onkologicznym w krajach rozwiniętych i ciągle narastającym w krajach rozwijających się. W Polsce rozpoznaje się obecnie ponad 15,7 tys. zachorowań rocznie, co odpowiada około 1/4 ogółu zachorowań na nowotwory u kobiet. Wzrost zagrożenia nowotworami piersi towarzyszy rozwojowi cywilizacyjnemu. W polskiej populacji wśród cywilizacyjnych czynników ryzyka szczególne znaczenie ma wydłużanie przeciętnego trwania życia (do 82 lat w ciągu ostatniego półwiecza) oraz zmiany związane z płodnością i dzietnością kobiet (wzrost wieku urodzenia pierwszego dziecka i zmniejszenie współczynnika dzietności). Szacuje się, że w ciągu najbliższych 15 lat liczba zachorowań w Polsce przekroczy 21 000, a zagrożenie tym nowotworem, chociaż nadal niższe, będzie porównywalne do obserwowanego w Europie (około 80/105) [1].
W Polsce, mimo zauważalnych postępów w walce z rakiem piersi, niepokojący jest wysoki poziom umieralności. W krajach o 1,5-2,5-krotnie wyższej zachorowalności (Polska $-50 / 10^{5}$, Wielka Brytania $-126 / 10^{5}$, Finlandia

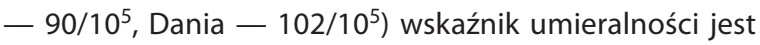
niewiele wyższy niż w Polsce (odpowiednio 14/10, $17 / 10^{5}$, $\left.15 / 10^{5}, 19 / 10^{5}\right)$ [2].

Na poprawę wyników leczenia, a tym samym obniżenie umieralności, wpływa szereg czynników, ale kluczową rolę odgrywa wczesne wykrycie nowotworu i bezzwłoczne podjęcie leczenia. Wyższy stopień zawansowania nowotworu w chwili rozpoznania ogranicza możliwości terapeutyczne, pogarsza rokowanie i obniża wskaźniki wyleczalności nowotworu [3].

Wprowadzone w niektórych krajach Europy w połowie lat 90. ubiegłego wieku populacyjne badania przesiewo- 
Tabela I. Struktura próby w podziale na ośrodki medyczne

\begin{tabular}{lccc}
\hline Ośrodek & $\begin{array}{c}\text { Liczba chorych na raka piersi } \\
\text { leczonych w ośrodku w 2010 r. }\end{array}$ & $\begin{array}{c}\text { Częstość względna } \\
\text { Liczba respondentek przebadanych } \\
\text { w ośrodku }\end{array}$ & $\mathbf{2 7 1}$ \\
\hline 1 & 2976 & 0,27 & $\mathbf{9 2}$ \\
3 & 1006 & 0,09 & $\mathbf{1 8 5}$ \\
4 & 2026 & 0,18 & $\mathbf{1 2 9}$ \\
5 & 1411 & 0,13 & $\mathbf{5 1}$ \\
6 & 559 & 0,05 & $\mathbf{6 1}$ \\
7 & 668 & 0,06 & $\mathbf{1 9}$ \\
8 & 211 & 0,02 & $\mathbf{4 5}$ \\
9 & 496 & 0,05 & $\mathbf{7 2}$ \\
Razem & $\mathbf{7 8 6}$ & 0,07 & $\mathbf{7 6}$ \\
\hline
\end{tabular}

we w kierunku raka piersi doprowadziły do spadku współczynników umieralności w grupie objętej skriningiem [4]. W polskiej populacji efekty wprowadzenia badań przesiewowych są mało widoczne z powodu niskiego uczestnictwa kobiet. Zaobserwowano jednak pewną poprawę w zakresie obniżenia stopnia zaawansowania nowotworu w momencie rozpoznania [1], chociaż rozpoczęcie leczenia przez chore na raka piersi w Polsce nadal jest opóźnione. Opóźnienie w podjęciu leczenia nie jest wyłącznie polskim doświadczeniem [3,5-13]. Wśród przyczyn opóźnienia wymieniane są przyczyny zależne od chorych, od lekarzy oraz systemu opieki zdrowotnej [14]. Opóźnienie ze strony chorych jest najczęściej definiowane jako czas, który upłynął od chwili zauważenia objawów sugerujących nowotwór do pierwszej wizyty u lekarza. Rokowanie u chorych na raka piersi, podobnie jak w innych chorobach nowotworowych, np. w czerniaku, jest lepsze, jeżeli rozpoznanie zostanie postawione w czasie krótszym niż 3 miesiące od pierwszych objawów klinicznych $[5,15]$. Na opóźnienie procesu diagnostyczno-terapeutycznego ze strony chorych wpływa szereg czynników, w tym wiek, stan społeczno-ekonomiczny, wykształcenie, czynniki etniczne, kulturowe i psychologiczne [3, 5, 6-9, 16-18]. Wszystkie te elementy warunkują w mniejszym lub większym stopniu zachowania zdrowotne i mogą wpływać na zmniejszenie lub zwiększenie opóźnienia. Najsilniejsze związki z opóźnieniem ze strony chorych dotyczą wieku i stanu społeczno-ekonomicznego. Chore starsze i o niższym statusie społeczno-ekonomicznym mają skłonność do odsuwania terminu porady lekarskiej $[5,17,18]$, natomiast wiedza na temat najbardziej typowych objawów choroby sprzyja wcześniejszemu zgłoszeniu do lekarza [10]. Niebagatelną rolę w podejmowaniu decyzji o rozpoczęciu leczenia ma nastawienie chorych, gdzie lęk przed nowotworem może być, zależnie od stopnia jego nasilenia, czynnikiem motywującym lub opóźniającym proces diagnostyczno-terapeutyczny $[15,19]$.
Celem niniejszej pracy było określenie przyczyn opóźnień w rozpoznaniu raka piersi i podjęciu leczenia u kobiet w Polsce. W niniejszej pracy przedstawiono przyczyny opóźnienia wynikające z postaw chorych. Systemowe przyczyny opóźnień będą przedmiotem odrębnego opracowania.

\section{Materiał i metody}

Badanie ankietowe przeprowadzono w sierpniu 2011 roku w grupie 1000 chorych na raka piersi, pochodzących z 10 ośrodków onkologicznych i szpitali z oddziałami onkologicznymi, wybranych losowo zgodnie z zasadami doboru grupowego. Prawdopodobieństwo wylosowania ośrodka było wprost proporcjonalne do liczby chorych na raka piersi, poddanych terapii w danym ośrodku w roku 2010. Warunkiem kwalifikacji pacjentek do udziału w badaniu było rozpoznanie raka piersi nie wcześniej niż na 6 miesięcy przed datą przeprowadzenia ankiety. Wywiady prowadzone były przez odpowiednio przeszkolone pielęgniarki zatrudnione w danej placówce, z wykorzystaniem elektronicznego kwestionariusza umieszczonego na przenośnym komputerze typu tablet. Ankieta zawierała pytania dotyczące czterech aspektów: danych demograficznych, czynników zależnych od pacjentki, czynników systemowych oraz oceny stopnia zaawansowania nowotworu w chwili rozpoczęcia leczenia. Przeprowadzone badanie pozwoliło uzyskać próbę reprezentatywną dla pacjentek leczonych z powodu raka piersi w Polsce w roku 2011. Badaną grupę charakteryzowały następujące cechy demograficzne: prawie $63 \%$ badanych było w wieku od 50 do 69 lat, niemal połowa (49\%) miała średnie wykształcenie; drugą najbardziej liczebną grupą były kobiety z wyższym wykształceniem (26\%). Przeważały kobiety zamieszkałe w miastach poniżej 50 tys. mieszkańców oraz na wsi (43\%); pacjentki z miast liczących powyżej 300 tys. mieszkańców stanowiły 38\% badanej zbiorowości. Strukturę próby z uwzględnieniem miejsca przeprowadzania wywiadów przedstawia tabela I. 


\section{Metody statystyczne}

Analiza statystyczna wykonana na potrzeby pracy zorientowana była na zmniejszenie liczby zmiennych, modelowanie relacji za pomocą analizy regresji oraz identyfikację współzależności par zmiennych. Redukcja danych dokonana za pomocą metody głównych czynników składowych umożliwiła wyodrębnienie mniejszej liczby bardziej ogólnych, jednak bezpośrednio niemierzalnych atrybutów, tak aby zachowana została jak największa część wariancji w oryginalnym zbiorze zmiennych [20]. Atrybuty te wykorzystane zostały w zastępstwie oryginalnych zmiennych, których wartości pozyskano za pomocą kwestionariusza. Służyły one jako predykatory w modelowaniu statystycznym, w celu obniżenia współliniowości i podniesienia stabilności równania regresji.

Poza wskazywaniem na czynniki psychologiczno-behawioralne w piśmiennictwie brakuje jednoznacznych przesłanek teoretycznych, pozwalających wybrać ograniczoną liczbę zmiennych niezależnych do równań regresji. W związku z tym badanie ma w pewnym stopniu charakter eksploracyjny. W efekcie przy konstruowaniu modelu opisującego determinanty czasu opóźnienia po stronie pacjentek przyjęto procedurę dwufazową. W pierwszym etapie wprowadzono do modelu 5 atrybutów uzyskanych w drodze analizy czynnikowej, a następnie wyboru pozostałych potencjalnych predyktorów dokonano za pomocą procesu selekcji postępującej, gdzie sukcesywnie dodawane są nowe zmienne niezależne, odznaczające się najwyższym poziomem korelacji cząstkowej ze zmienną zależną i jednocześnie będące statystycznie istotnymi parametrami modelu. Proces tworzenia modelu kończy się, gdy żadna z niewybranych zmiennych niezależnych nie powiększa w istotny sposób wyjaśnianej wariancji zmiennej zależnej [21]. Do zbioru zmiennych, będących potencjalnymi składowymi modelu, obok atrybutów wyodrębnionych w drodze analizy czynnikowej wprowadzono wszystkie mierzone charakterystyki respondentów, które mogły mieć związek z czasem pomiędzy pierwszymi objawami sugerującymi raka piersi a zgłoszeniem się na badanie do lekarza. Jakość końcowego równania regresji została zweryfikowana ze względu na normalność rozkładu, autokorelację składników resztowych, współliniowość zmiennych niezależnych oraz heteroskedastyczność. Ze względu na ograniczenie miejsca wyniki testów diagnostycznych nie zostały tu podane, aczkolwiekżaden z nich nie wskazywał na istnienie problemów ze zgodnością pomiędzy danymi empirycznymi a założeniami związanymi ze stosowaniem tej metody.

W pracy wykorzystano również miary korelacji pomiędzy parami zmiennych. W tym celu posłużono się współczynnikami korelacji liniowej Pearsona (tam gdzie zmienne mierzone były na skali interwałowej lub miały charakter dychotomiczny), skorygowanej korelacji rangowej Spearmana z poprawką uwzględniającą rangi wiązane (jeśli część zmiennych w grupie porównywanych par wykorzystywała skale porządkowe) lub test niezależności $\chi^{2}$ (jeśli badane cechy miały charakter nominalny) $[22,23]$.

\section{Wyniki \\ Okoliczności zauważenia przez pacjentki objawów raka piersi}

Jedno z kluczowych pytań w ankiecie dotyczyło okoliczności, w jakich pacjentki po raz pierwszy zauważyły objawy mogące wskazywać na raka piersi. Odpowiedzi umożliwiły wyodrębnienie kobiet, które same zidentyfikowały niepokojące objawy i które mogły mieć świadomy wpływ na czas, jaki upłynął do momentu wizyty u lekarza w celu określenia charakteru zmian. Tylko w przypadku tej grupy kobiet można mówić o wystąpieniu opóźnień w diagnostyce, za które same ponosiły odpowiedzialność. W odniesieniu do pozostałych kobiet okres realizacji procesu diagnostycznego determinowany był przez czynniki systemowe, związane ze sprawnością miejscowego systemu ochrony zdrowia. Wobec powyższego uwarunkowania wystąpienia opóźnień z przyczyn pacjentek analizowano w odniesieniu do 56\% grupy badanej. U pozostałych chorych objawy sugerujące raka piersi stwierdzono podczas badania lekarskiego z innego powodu (9,9\%) lub w wyniku incydentalnej lub przesiewowej mammografii (34\%).

\section{Czas od wykrycia objawów przez pacjentkę do momentu umówienia się na wizytę u lekarza}

Pierwszym ocenianym okresem był czas, jaki upłynął od dnia zauważenia przez kobietę objawów mogących wskazywać na raka piersi do momentu rejestracji w przychodni lub szpitalu „na wizytę" u lekarza. W grupie chorych, które same zauważyły objawy nowotworu, $41 \%$ było w wieku poniżej 50 lat, podczas gdy wśród respondentek, u których dokonano identyfikacji pierwszych objawów w trakcie badań, ta grupa wiekowa stanowiła zaledwie $18 \%$. Osoby, które same odkryły niepokojące objawy, częściej niż pozostałe respondentki mieszkały na wsi (odpowiednio $26 \%$ do $14 \%$ ), a rzadziej w miastach powyżej 500 tys. mieszkańców (26\% do 30\%), jednak miały podobną strukturę wykształcenia $(9,2 \%$ osób z wykształceniem podstawowym, 16\% z zawodowym, $48 \%$ ze średnim oraz $27 \%$ z wyższym) — różnica nieznamienna.

Rozkład odpowiedzi przedstawiono na rycinie 1. Przypisując każdej kategorii reprezentującej dany czas opóźnienia odpowiadający jej środek przedziału, wyliczono średni czas opóźnienia po stronie pacjentki, który w tym wypadku wyniósł 3,6 tygodnia, przy czym u 28\% chorych przekraczał on 4 tygodnie.

\section{Czynniki psychologiczne i behawioralne wpływajq̨ce na postawy pacjentek}

Kolejne pytania pozwoliły na uzyskanie odpowiedzi, jakie czynniki najsilniej wpływają na zachowania kobiet, 
Tabela II. Ładunki czynnikowe dla poszczególnych zmiennych uwzględnionych w kwestionariuszu (macierz poddana rotacji metodą Varimax; wycieniowano najwyższe ładunki czynnikowe dla poszczególnych zmiennych, sugerujące który czynnik najlepiej reprezentuje daną zmienną)

\begin{tabular}{|c|c|c|c|c|c|}
\hline \multirow{2}{*}{$\begin{array}{l}\text { Zmienne wykorzystane w skali Likerta do pomiaru uwarunkowań psychologiczno- } \\
\text { behawioralnych respondentek }\end{array}$} & \multicolumn{5}{|c|}{ Czynnik } \\
\hline & 1 & 2 & 3 & 4 & 5 \\
\hline Regularnie sprawdzałam swoje piersi pod kątem objawów raka & 066 & $-0,053$ & 0,870 & $-0,051$ & 0,019 \\
\hline Odkryłam objawy raka podczas samobadania piersi & $-0,046$ & 0,012 & 0,857 & $-0,071$ & $-0,031$ \\
\hline $\begin{array}{l}\text { Na początku nie sądziłam, że objawy, które odkryłam, to nowotwór } \\
\text { — wydawało mi się, że to nic poważnego i przejdzie samo, bez wizyty u lekarza }\end{array}$ & $-0,118$ & 0,785 & $-0,032$ & 0,200 & 0,072 \\
\hline Byłam przekonana, że objawy, które zauważyłam, są związane z łagodną odmianą nowotworu & $-0,024$ & 0,826 & 0,109 & 0,059 & 0,066 \\
\hline Natychmiast zorientowałam się, że to może być coś poważnego, może nawet rak piersi & 0,113 & $-0,808$ & 0,141 & 0,037 & 0,104 \\
\hline $\begin{array}{l}\text { Zaraz po zauważeniu objawów powiedziałam o tym innej osobie, } \\
\text { której ufam (mężowi, matce, ojcu, dziecku, przyjaciółce itp.) }\end{array}$ & 0,090 & $-0,009$ & 0,128 & $-0,237$ & 0,818 \\
\hline $\begin{array}{l}\text { O tym, aby pójść do lekarza, przekonała mnie inna, bliska mi osoba, } \\
\text { której opowiedziałam o objawach }\end{array}$ & $-0,032$ & 0,056 & $-0,203$ & 0,383 & 0,669 \\
\hline Po odkryciu problemów z moją piersią starałam się o tym nie myśleć & $-0,436$ & 0,140 & $-0,162$ & 0,358 & 0,043 \\
\hline Na początku trudno było mi znaleźć czas, aby pójść do lekarza & $-0,222$ & 0,153 & $-0,116$ & 0,619 & $-0,056$ \\
\hline $\begin{array}{l}\text { Odkrycie objawów mogących wskazywać na raka piersi spowodowało, } \\
\text { że nie mogłam przestać o tym myśleć }\end{array}$ & 0,773 & $-0,075$ & $-0,010$ & $-0,063$ & 0,114 \\
\hline $\begin{array}{l}\text { Po odkryciu objawów mogących wskazywać na raka piersi byłam przerażona } \\
\text { możliwymi konsekwencjami }\end{array}$ & 0,837 & $-0,022$ & $-0,031$ & 0,180 & 0,000 \\
\hline Bardzo bałam się, że może to być rak piersi & 0,852 & $-0,108$ & 0,007 & 0,119 & $-0,019$ \\
\hline Nie wierzyłam, że raka piersi można skutecznie wyleczyć & 0,205 & 0,005 & $-0,053$ & 0,590 & $-0,082$ \\
\hline W mojej ocenie wizyta u lekarza jest zazwyczaj nieprzyjemnym doświadczeniem & 0,120 & 0,031 & 0,050 & 0,679 & 0,115 \\
\hline
\end{tabular}

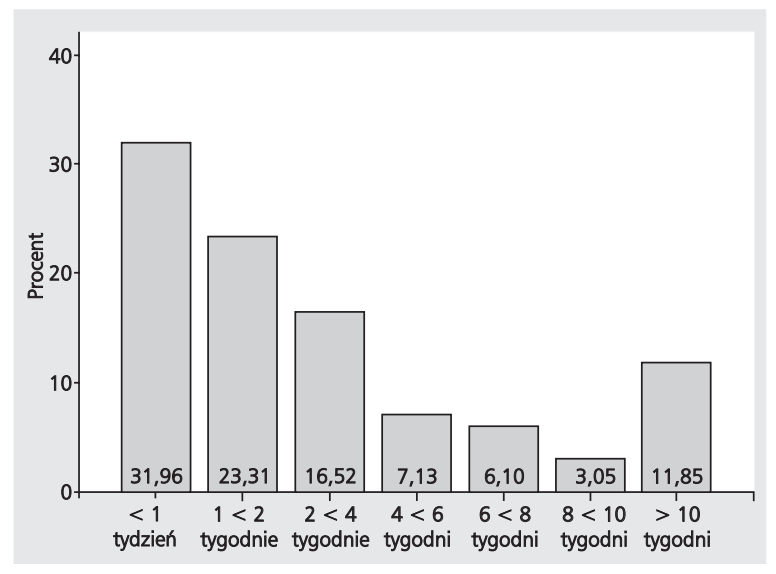

Rycina 1. Czas, jaki upłynął, od momentu wykrycia przez pacjentkę pierwszych objawów raka piersi do momentu rejestracji „na wizytę" u lekarza

które same zauważyły u siebie objawy sugerujące raka piersi. Analiza czynnikowa umożliwiła redukcję 14 zmiennych mierzących różne aspekty psychologiczne i behawioralne pacjentek do 5 bardziej ogólnych atrybutów, które łącznie wyjaśniały $63 \%$ wariancji w obrębie oryginalnego zbioru charakterystyk. Na podstawie wartości tzw. ładunków czynnikowych, które określają siłę korelacji indywidualnych zmiennych z uzyskanymi czynnikami przedstawionymi w tabeli ll, dokonano interpretacji zidentyfikowanych czynników, nadając im umowne etykiety, wyróżniając: lęk przed konsekwencjami raka piersi (Lęk), lekceważenie i racjonalizację do- strzeżonych objawów (Lekceważenie), nawyk samobadania (Samobadanie), brak zaufania do systemu ochrony zdrowia (Nieufność) i wpływ bliskich osób (Bliscy).

Stwierdzono następujące znamienne zależności otrzymanych czynników ze zmiennymi określającymi cechy demograficzne i społeczno-ekonomiczne pacjentek:

1. Lęk był odczuwany silniej przez pacjentki w młodszym wieku $(R=-0,147 ; p=0,001)$, lepiej wykształcone $(R=0,109$; $\mathrm{p}=0,012$ ) oraz te, $\mathrm{u}$ których rozpoznanie ustalono w prywatnej placówce ochrony zdrowia $(R=-0,115$; $p=0,008)$.

2. Lekceważenie było silniejsze dla respondentek z niższym wykształceniem ( $R=-0,121 ; p=0,005)$, mieszkanek miejscowości $<300$ tys. mieszkańców $(R=-0,116 ; p=0,008)$ oraz kobiet $w$ wieku powyżej 49 lat $(R=0,104 ; p=0,016)$,

3. Samobadanie piersi było deklarowane częściej u młodszych $(R=-0,121 ; p=0,005)$ i lepiej wykształconych kobiet $(R=0,156 ; p<0,001)$ oraz tych, u których rozpoznanie ustalono w prywatnej placówce ochrony zdrowia $(R=-0,126 ; p=0,004)$,

4. Poziom nieufności był znamiennie związany jedynie z poziomem wykształcenia — kobiety mniej wykształcone deklarowały wyższy poziom nieufności wobec systemu opieki medycznej i szans na udane leczenie $(R=-0,191 ; p<0,001)$.

5. Pacjentki nieco częściej dzieliły się swoimi obawami i ulegały sugestiom bliskich osób, jeśli miały niższe wykształcenie $(R=-0,094 ; p=0,031)$ i były w starszym wieku $(R=0,134 ; p=0,002)$. 
Tabela III. Model regresji wielorakiej pomiędzy czasem opóźnienia ze strony pacjentki a czynnikami psychologiczno-behawioralnymi

\begin{tabular}{|c|c|c|c|c|c|c|c|}
\hline & \multicolumn{2}{|c|}{$\begin{array}{c}\text { Współczynniki } \\
\text { niestandaryzowane }\end{array}$} & \multirow{2}{*}{$\begin{array}{c}\begin{array}{c}\text { Współczynniki } \\
\text { standaryzowane }\end{array} \\
\text { Beta }\end{array}$} & \multirow[b]{2}{*}{$\mathrm{t}$} & \multirow[b]{2}{*}{ Istotność } & \multicolumn{2}{|r|}{$\begin{array}{c}\text { Statystyki } \\
\text { współliniowości }\end{array}$} \\
\hline & B & Błąd standardowy & & & & Tolerancja & VIF (Variance Inflation Factor) \\
\hline (Stała) & 3,581 & 0,151 & & 23,652 & 0,000 & & \\
\hline Lęk & $-0,525$ & 0,151 & $-0,131$ & $-3,474$ & 0,001 & 1,000 & 1,000 \\
\hline Lekceważenie & 1,178 & 0,151 & 0,293 & 7,781 & 0,000 & 1,000 & 1,000 \\
\hline Samobadanie & $-0,954$ & 0,152 & $-0,237$ & $-6,286$ & 0,000 & 1,000 & 1,000 \\
\hline Nieufność & 1,294 & 0,152 & 0,321 & 8,508 & 0,000 & 1,000 & 1,000 \\
\hline Bliscy & $-0,251$ & 0,151 & $-0,062$ & $-1,658$ & 0,098 & 1,000 & 1,000 \\
\hline
\end{tabular}

Tabela IV. Miary stopnia dopasowania modelu regresji do danych empirycznych

\begin{tabular}{|c|c|c|c|c|c|c|c|c|}
\hline \multirow[t]{2}{*}{ R } & \multirow[t]{2}{*}{ R-kwadrat } & \multirow[t]{2}{*}{ Skorygowane R-kwadrat } & \multirow[t]{2}{*}{ Błąd standardowy oszacowania } & \multicolumn{5}{|c|}{ Statystyki zmiany } \\
\hline & & & & $\begin{array}{c}\text { Zmiana } \\
\text { R-kwadrat }\end{array}$ & F zmiany & df1 & df2 & $\begin{array}{l}\text { Istotność F } \\
\text { zmiany }\end{array}$ \\
\hline 0,514 & 0,264 & 0,256 & 3,49304 & 0,264 & 31,078 & 6 & 519 & $p<0,001$ \\
\hline
\end{tabular}

Tabela V. Model regresji wielorakiej pomiędzy czasem opóźnienia ze strony pacjentki a czynnikami psychologiczno-behawioralnymi oraz charakterystykami demograficznymi

\begin{tabular}{|c|c|c|c|c|c|}
\hline \multirow[t]{2}{*}{ Parametry modelu } & \multicolumn{2}{|c|}{ Współczynniki niestandaryzowane } & \multirow{2}{*}{$\begin{array}{c}\text { Współczynniki standaryzowane } \\
\text { Beta }\end{array}$} & \multirow[t]{2}{*}{$\mathrm{t}$} & \multirow[t]{2}{*}{ Istotność } \\
\hline & B & Błąd standardowy & & & \\
\hline (Stała) & 2,465 & 0,592 & & 4,166 & 0,000 \\
\hline Wiek zdychotomizowany $(\leq 49 ;>49)$ & 0,674 & 0,338 & 0,077 & 1,997 & 0,046 \\
\hline Lęk & $-0,484$ & 0,154 & $-0,119$ & $-3,148$ & 0,002 \\
\hline Lekceważenie & 10,146 & 0,153 & 0,283 & 7,477 & 0,000 \\
\hline Samobadanie & $-0,900$ & 0,154 & $-0,222$ & $-5,850$ & 0,000 \\
\hline Nieufność & 1,280 & 0,152 & 0,316 & 8,397 & 0,000 \\
\hline Bliscy & $-0,231$ & 0,152 & $-0,057$ & $-1,516$ & 0,130 \\
\hline
\end{tabular}

\section{Czas pomiędzy zauważeniem przez pacjentkę objawów a zgłoszeniem się na wizytę do lekarza}

Aby ocenić w jakim stopniu czynniki psychologiczno-behawioralne determinowały czas opóźnienia ze strony pacjentki, podjęto próbę stworzenia równania regresji wielorakiej, uwzględniającej jako zmienne zależne pięć wyodrębnionych czynników. Wyniki analizy regresji przedstawia tabela III.

Największy wpływ na opóźnienie podjęcia procesu diagnostyki i leczenia miała nieufność pacjentek wobec systemu ochrony zdrowia i brak wiary w wyniki terapii. Niewiele mniejsze negatywne znaczenie miały okazywane przez pacjentki postawy lekceważenia i racjonalizacji. Wyraźny wpływ na skrócenie okresu opóźnienia miał nawyk samobadania piersi oraz lęk, który wydawał się skłaniać kobiety do szybszej wizyty u lekarza. Wpływ bliskich nie miał istotnego znaczenia na czas opóźnienia. Próba uzupełnienia powyższego modelu o dodatkowe charakterystyki respondentek pozwoliła dodać do wykorzystanych powyżej zmiennych niezależnych jedynie dychotomizowany wiek, gdzie pacjentki podzielono na dwie grupy: do 50. i po 50. roku życia. Zmienna ta miała względnie niewielki wpływ na czas opóźnienia; u kobiet starszych było one dłuższe o 0,67 tygodnia (tabela IV i V). Nowy model charakteryzował się tylko nieznacznie wyższym poziomem wyjaśniania wariancji w odniesieniu do czasu opóźnienia (R-kwadrat $=0,264$ )

\section{Dyskusja}

Niniejsze badanie jest składową międzynarodowego projektu realizowanego równolegle w 10 krajach. Wstępne wyniki przedstawione zostały $\mathrm{m}$. in. w trakcie Kongresu Amerykańskiego Towarzystwa Onkologii Klinicznej (ASCO) w 2012 roku [24]. Spośród 4816 kobiet objętych badaniem 2870 (52\%) samo zwróciło uwagę na objawy sugerujące rozpoznanie raka piersi i z własnej inicjatywy podjęło dalsze kroki diagnostyczno-lecznicze. W przedstawionej w niniejszej pracy populacji polskiej udział ten stanowił $56 \%$ badanych. Oznacza to, że u ponad 56\% kobiet choroba osiągnęła 
fazę manifestującą się klinicznie, co najmniej miejscową. Dominującym i najczęściej jedynym objawem, który wzbudził podejrzenie nowotworu, był guz w piersi (79\% chorych w tej grupie). U pozostałych $44 \%$ diagnostyka została wdrożona jako kolejny etap postępowania po wykryciu zmiany podczas badania lekarskiego lub w wyniku incydentalnej lub przesiewowej mammografii [24].

Stale aktualna jest obserwacja, że więcej rozpoznań raka piersi powstaje na podstawie objawów klinicznych niż w wyniku badań przesiewowych. Stopień zaawansowania klinicznego w chwili rozpoczęcia terapii odgrywa zasadniczą rolę w wyborze kolejności i rodzaju leczenia i pozostaje jednym z czynników determinujących rokowanie oraz wyniki leczenia. Wielokrotnie cytowana analiza 87 badań obserwacyjnych wykazała, że opóźnienie procesu diagnostyczno-terapeutycznego o 3-6 miesięcy powoduje skrócenie czasu przeżycia chorych na raka piersi [3].

Autorzy doniesień dotyczących opóźnienia w leczeniu raka piersi zgodnie podkreślają, że rozpoczęcie procesu diagnostyczno-terapeutycznego dopiero w chwili zauważenia objawów klinicznych choroby jest samo w sobie zasadniczym czynnikiem opóźnienia terapii [9, 18, 25]. Przy takiej interpretacji należałoby przyjąć, że 56\% badanej przez nas grupy ma opóźnienie w leczeniu wynikające z rozpoczęcia diagnostyki dopiero po wystąpieniu objawów nowotworu.

W retrospektywnym badaniu dotyczącym grupy 5464 kobiet Stuver i wsp. [9] rozpoznali opóźnienie w grupie 938 kobiet (17\%), określając je jako czas powyżej 90 dni od chwili spostrzeżenia objawów choroby do ostatecznego rozpoznania opartego na wyniku biopsji. Czynnikami ryzyka powstania opóźnienia był młody wiek, przynależność do mniejszości etnicznych i samodzielne spostrzeżenie klinicznych objawów raka.

W wielu doniesieniach punktem wyjściowym do rozpoczęcia badania był czas opóźnienia powyżej 60 dni [8, 18], a średnie wartości oscylowały w przedziale od 13 dni [5, 12] do ponad 2 miesięcy [7], zależnie od wieku, wykształcenia, rasy, miejsca zamieszkania i roli lekarzy rodzinnych w edukacji zdrowotnej [10, 26-28].

W niniejszym materiale, w grupie 562 kobiet, które same zwróciły uwagę na objawy mogące sugerować raka piersi, średni czas opóźnienia wynikającego z ich postaw wynosił 3,6 tygodnia, a udział chorych z opóźnieniem 4 tygodni wynosił $28 \%$.W międzynarodowym badaniu, którego część stanowi niniejsze opracowanie, średnia wartość opóźnienia wynosiła 4,7 tygodnia (od 3,4 do 6,2 tygodnia), a 39\% badanych miała opóźnienie przekraczające 4 tygodnie [24]. Mimo że korzystne na tle innych ocenianych państw, wyniki naszego badania można uznać za nadal niezadowalające, gdyż już 10 lat temu w materiale Arndta i wsp. [5] opóźnienie ze strony chorych wynosiło średnio 13 dni i było istotnie krótsze niż publikowane dekadę wcześniej.
Nie potwierdzono sugerowanego w niektórych doniesieniach niekorzystnego wpływu młodego wieku (<40. r. ̇̇.) na opóźnienie procesu diagnostyczno-terapeutycznego $[9,18]$. Zgodnie natomiast z obserwacjami innych autorów [5] stwierdzono znamienny wpływ na opóźnienie leczenia z powodu czynników, takich jak niechęć do systemu opieki zdrowotnej, braku wiary w skuteczne leczenie, lekceważenie objawów choroby czy starszy wiek. Z kolei czynnikami związanymi ze zmniejszeniem opóźnienia leczenia były, podobnie jak w innych doniesieniach $[8,10,12,15]$, motywujący do działania wpływ lęku i wyższa kultura zdrowotna, przejawiająca się nawykiem samobadania piersi i rozumieniem potrzeby reagowania na niepokojące objawy kliniczne.

Zachowania zdrowotne (health behavior), których istotną częścią jest zgłaszanie się do lekarza w momencie zauważenia zmian w stanie zdrowia, zależą od wielu czynników, wśród których niebagatelną rolę odgrywają uwarunkowania psychologiczne. Spośród wielu modeli wyjaśniających te procesy na szczególną uwagę zasługują trzy: model HBM, TRA i SET.

Model HBM (health belief model) obejmuje przekonania zdrowotne, zawierające 4 główne składowe [29]:

1. Spostrzeganie prawdopodobieństwa osobistej podatności, czyli stopnia zagrożenia własnego stanu zdrowia.

2. Spostrzegania powagi sytuacji (na ile dostrzegana zmiana czy choroba są poważne).

3. Ocena strat wynikających z podjęcia decyzji (o działaniu lub wstrzymaniu się od działania).

4. Ocena zysków osiągniętych w następstwie podjęcia decyzji (o działaniu lub jego zaniechaniu).

Uzupełnieniem modelu HBM jest model opierający się na teorii własnej skuteczności SET (selfefficacy theory), który także obejmuje 4 elementy [30]:

1. Historia własnych wcześniejszych porażek i sukcesów.

2. Doświadczenia zastępcze (uzyskane drogą obserwacji zachowań innych osób).

3. Informacje zwrotne o własnej skuteczności (działaniach podejmowanych wcześniej).

4. Stan fizjologiczny (subiektywna ocena własnego stanu zdrowia, mierzona samopoczuciem).

Z kolei model TRA, bazujący na teorii uzasadnionego działania (theory reasoned action), uzupełnia wyżej opisane modele o dwa ważne elementy [31]:

1. Przekonanie o skuteczności podejmowanego działania

2. Uwzględnianie opinii otoczenia o skuteczność działania (role opinii społecznej i ważnych dla człowieka osób, np. rodziny, na temat podejmowania przez niego działania).

3. Przedstawione wyżej modele zachowań zdrowotnych wyjaśniają w dużej mierze uzyskane w pracy wyniki badań.

Istotnym czynnikiem motywującym do zgłoszenia się do lekarza i podjęcia czynności diagnostycznych był lęk. 
Lęk jest reakcją na poczucie zagrożenia (prawdopodobieństwo wykrycia poważnej choroby) oraz przewidywania "zysków", tj. korzyści z szybko podjętego leczenia (wg modelu HBM), przeważającego nad stratami (przykrymi objawami ubocznymi) [32]. Lękową reakcję stwierdzono przede wszystkim u kobiet młodszych i lepiej wykształconych. Można przypuszczać, że wiedza tych osób na temat choroby nowotworowej i uwarunkowań skuteczności jej leczenia jest wyższa niż w grupie starszych i gorzej wykształconych [33].

Silniejszy lęk u kobiet, u których rozpoznanie ustalono w prywatnych placówkach służby zdrowia, może wskazywać dodatkowo na lękowe wzmocnienie motywacji tych osób do szybkiego zgłoszenia się do lekarza po zauważeniu niepokojących objawów i decyzję szybszego — z ominięciem „zwykłej kolejki” — zgłoszenia się do lekarza.

Wszystkie omówione wyżej czynniki można także odnieść do spostrzeżenia, że regularne samobadanie piersi deklarują częściej kobiety młodsze i lepiej wykształcone, u których rozpoznanie ustalono w prywatnych placówkach ochrony zdrowia. Wyniki badań wskazują zatem jednoznacznie na rolę lęku jako czynnika motywującego do korzystnych zachowań zdrowotnych badanych kobiet. Jednocześnie jednak w wielu doniesieniach podkreśla się zjawisko paraliżującego wpływu zbyt silnego lęku w takich sytuacjach [34]. W przypadku lęku o bardzo silnym natężeniu odczuwany dyskomfort może być tak duży, że człowiek zaczyna stosować tzw. mechanizmy obronne celem jego zmniejszenia [35]. Przykładem mogą tu być kobiety stosujące mechanizm unikania (prezentowany np. w wypowiedzi „po odkryciu problemów z moją piersią starałam się o tym nie myśleć"). Z kolei kobiety mniej wykształcone deklarowały w badaniu wyższy poziom nieufności wobec systemu opieki zdrowotnej i skuteczności leczenia, odwołując się przy tym do opinii i sugestii bliskich sobie osób. Zachowania tego rodzaju mogą wynikać z mniejszego przekonania co do skuteczności własnych decyzji i większego liczenia się z opinią otoczenia, tj. grupy ważnych dla człowieka osób (zgodnie z modelem TRA). Mogą też tu mieć miejsce negatywne doświadczenia zastępcze (straszenie przykładem chorych, którym się nie powiodło w walce z chorobą — dość częste w niektórych środowiskach).

Uzyskane wyniki wskazują zatem wyraźnie, że psychologiczne uwarunkowania zachowań zdrowotnych badanych kobiet mają charakter wieloaspektowy, co z kolei rzutuje na rodzaj propozycji działań w kierunku ich poprawy. Kształtując politykę zdrowotną w obszarze profilaktyki raka piersi, należy brać pod uwagę przekonania chorych na temat zdrowia i choroby. $Z$ drugiej strony trzeba również pamiętać, że ludzie nie zawsze postępują racjonalnie bardzo często ich decyzje pozostają pod wpływem silnych emocji - zwłaszcza lęku. O ile średnie natężenie okazuje się korzystne dla zachowań prozdrowotnych, o tyle należy zmniejszyć jego zbyt wysoki poziom. Niewątpliwie istnieje konieczność szeroko pojętej edukacji na temat choroby i roli szybkiej diagnostyki oraz leczenia w aspekcie przewagi zysków (wyleczenia, przedłużenia życia) w stosunku do strat (uciążliwości leczenia). Bardzo ważne jest także podjęcie działań w kierunku kształtowania postaw społecznych, zwłaszcza w mniejszych miejscowościach. W działaniach tego typu skuteczne może być dostarczanie pozytywnych doświadczeń zastępczych (np. w formie opisu sytuacji takich chorych, u których leczenie przyniosło spodziewane efekty), a także bardzo zdecydowane prostowanie błędnych (i wciąż dość powszechnych) przekonań o zbyteczności badań kontrolnych w przypadkach dobrego samopoczucia (przedstawianych w stwierdzeniu: „Czuję się zdrowa, więc po co się badać?"). Należy pamiętać, że zgłoszenie się do lekarza bardzo często jest wynikiem całego ciągu zdarzeń psychicznych i społecznych, takich jak: dostrzeżenie zmiany w stanie zdrowia, przekonania zdrowotne, reakcje emocjonalne (głównie lęk), więzi społeczne. Wszystkie te czynniki należy brać pod uwagę, planując edukację zdrowotną.

Podsumowując, działania na rzecz zmniejszenia opóźnienia w podjęciu rozpoznania i leczenia raka piersi w Polsce powinny zatem polegać na osłabianiu udziału czynników opóźniających rozpoznanie oraz wzmacnianiu udziału czynników zmniejszających to opóźnienie. Szeroko pojęta edukacja zdrowotna powinna nieść ładunek wiedzy i pozytywnych emocji, w tym: informować o poprawie wyników leczenia raka piersi w Polsce, nieustannie edukować w zakresie objawów sugerujących podejrzenie nowotworu piersi, zwiększać czujność wobec postrzeganych objawów, zachęcać do niezwłocznego zgłaszania się do lekarza, osłabiać paraliżujący przed działaniem lęk na rzecz poziomu lęku motywującego do zachowań prozdrowotnych, a także zniechęcać do lekceważenia objawów i odkładania terminu badania.

\section{Podziękowania}

Dziękujemy dyrektorom następujących instytucji za umożliwienie przeprowadzenia badania ankietowego będącego podstawa niniejszego opracowania. W kolejności alfabetycznej miast wymieniamy je poniżej: Centrum Onkologii im. Franciszka Łukaszczyka w Bydgoszczy, Wojewódzki Szpital Specjalistyczny im. NMP w Częstochowie, Wojewódzkie Centrum Onkologii w Gdańsku, Centrum Onkologii Ziemi Lubelskiej im. Św. Jana z Dukli w Lublinie, Wojewódzki Szpital Specjalistyczny im. Mikołaja Kopernika w Łodzi, Szpital Klinicznego Przemienienia Pańskiego UM w Poznaniu, Szpital Wojewódzki Św. Łukasza w Tarnowie, Centrum Onkologii Instytut im. Marii Skłodowskiej-Curie w Warszawie, Klinika Onkologiczna przy Wawelskiej Centrum Onkologii Instytut im. Marii Skłodowskiej-Curie w Warszawie, Dolnośląskie Centrum Onkologii we Wrocławiu. 
Prof. dr hab. n. med. Sylwia Grodecka-Gazdecka

Katedra i Klinika Onkologii

Uniwersytet Medyczny

im. Karola Marcinkowskiego

ul. Szamarzewskiego 82/84, 60-569 Poznań

e-mail: sylwia.grodecka-gazdecka@skpp.edu.pl

Otrzymano: 2 kwietnia $2013 \mathrm{r}$.

Przyjęto do druku: 11 kwietnia 2013 r.

\section{Piśmiennictwo}

1. Didkowska J, Wojciechowska U. Nowotwory piersi w Polsce i Europie - populacyjny punkt widzenia. Nowotwory 2013; (praca przyjęta do druku).

2. Ferlay J, Shin HR, Bray F i wsp. GLOBOCAN 2008 v2.0, Cancer Incidence and Mortality Worldwide. IARC CancerBase No. 10 [Internet]. Lyon, France: International Agency for Research on Cancer; 2010. Dostęp z dnia 23.01.2013.

3. Richards MA, Westcombe AM, Love SB i wsp. Influence of delay on survival in patients with breast cancer: a systematic review. Lancet 1999; 353: 1119-1126.

4. Haukka J, Byrnes G, Boniol M i wsp. Trends in Breast Cancer Mortality in Sweden before and after Implementation of Mammography Screening. PLoS One 2011; 6: e22422. Published online 2011 September 26. doi: 10.1371/journal.pone.0022422 PMCID: PMC3180283.

5. Arndt V, Stürmer T, Stegmaier C i wsp. Patient delay and stage of diagnosis among breast cancer patients in Germany - a population based study. Br J Cancer 2002; 86: 1034-1040.

6. Williams DL, Tortus S, Thomson J. Factors associated with delays of diagnosis and treatment of breast cancer in women in a Louisiana urban safets net hospital. Women Health 2010; 50: 705-718.

7. Chintamani, Tyteja A, Khandelwal Ri wsp. Patients and provider delays in breast cancer patients attending a tertiary care centre: a prospective study. JRSM Short Rep 2011 doi: 10.1258/shorts.2011.011006.

8. Norsa'adah B, Rampal KG, Rahmah MA i wsp. Diagnosis delay of breast cancer and its associated factors in Malaysian women. BMC Cancer 2011;11:141-149.

9. Stuver SO, Zhu J, Simchowitz B i wsp. Identifying women at risk of delayed breast cancer diagnosis. Jt Comm J Qual Pateint Saf 2011; 37: 568-575.

10. Burgess CC, Hunter MS, Ramirez AJ. A qualitative study of delay among women reporting symtoms of breast cancer. Psychooncology 2006; 962: 968.

11. O'Mahoney $M$, Hegarty J. Factors influencing women in seeking help from a health care professional on self discovery of a breast symptom, in an Irish context. J Clin Nursing 2009; 18: 2020-2029.

12. Nosarti C, Crayford T, Roberts JV i wsp. Delay in presentation of symptomatic referrals to a breast clinic: patient and system factors. $\mathrm{Br}$ J Cancer 2000; 82: 742-748.

13. Unger-Saldana K, Infante-Castaneda C. Delay of medical care for symptomatic breast cancer: a literature review. Salud Publica Mex. 2009; 51: 270-285.

14. Hansen RP, Vedsted P, Sokolowski I i wsp. Time intervals from first symptom to treatment of cancer: a cohort study of 2,212 newly diagnosed cancer patients. BMC Health Services Research 2011;11:284-291.
15. Dubayova T, van Dijk JP, Nagyova I i wsp. The impact of the intensity of fear on patient's delay reagrading health care seeking behavior: a systemic review. Int J Public Health 2010; 55: 459-468.

16. Richardson JL, Langholz B, Bernstein L. Stage and delay in breast cancer diagnosis by race, socioeconomic status, age and year. $\mathrm{Br} J$ Cancer 1992; 65: 922-926.

17. Caplan LS, Helzlsouer KJ. Delay in breast cancer: a review of the literature. Public Health Rev 1992; 20: 187-214.

18. Partridge $\mathrm{AH}$, Hughes $\mathrm{ME}$, Ottesen RA i wsp. The effect of age on delay in diagnosis and stage of breast cancer. Oncologist 2012; 17: 775-782.

19. Bish A, Ramirez A, Burgess C i wsp. Understanding why women delay in seeking help for breast cancer symptoms. J Psychosomatic Res 2005; 58: 321-326.

20. Allgar VL, Neal RP. Delays in the diagnosis of six cancers: analysis of data from the National Survey of NHS Patients. Cancer Br J Cancer 2005; 92: 1959-1970.

21. Fisher LD, van Belle G, Heagerty PJ, Lumley T. Biostatistics: A Methodology for the Health Sciences. Wyd. 2 Hiboken, New Jersey, John Willey \& Sons, 2004.

22. Armitage P, Berry G, Matthews JNS. Statistical Methods in Medical Research. Wyd. 4, Malden, Massachusetts; Blackwell; 2002.

23. Leech NL, Barrett KC, George AM. SPSS for Intermediate Statistics: Use and Interpretation. Wyd. 2, Mahwah, New Jersey, Lawrence Erlbaum Associates, Inc.; 2005.

24. Jassem J, Bacanu F, Eglitis J i wsp. Patient-related factors influencing time between first signs of breast cancer (BC) and appointment for medical visit (AMV) - an international survey. 2012 ASCO Annual Meeting Proceedings; 48th Annual Meeting, Chicago, [USA], June 1-5, 2012.

25. Montella M, Crispo A, Aiuto GD i wsp. Determinant factors for diagnostic delay in operable breast cancer patients. Eur J Cancer 2001; 10: 53-59.

26. Pruitt SL, Shim M, Mullen PD i wsp. Association of area socioeconomic status and breast, cervical and colorectal cancer screening: a systemic review. Cancer Epiedmiol Biomarkers Prev 2009; 18: 2579-2599.

27. Reeler A, Qiao Y, Dare L i wsp. Women's cancers in developing countries: from research to an Integrated Systems Approach. Asian Pac J. Center 2009; 10: 519-526.

28. Heisey R, Clemons M, Granek Li i wsp. Health care strategies to promote earlier presentataion of symptomatic breast cancer: perspectives of women and family physicians. Curr Oncol. 2011; 18: e227-237.

29. Janz NK, Becker MH. The health belief model: a decade later. Health Educ. Q 1984; 11: 1-47.

30. Sheridan LC, Radmacher SA. Psychologia zdrowia. Warszawa: Instytut Psychologii Zdrowia, Polskie Towarzystwo Psychologiczne; 1998, 268-270.

31. Paskett ED, McLaughlin JM, Breast Cancer Screening. W: Holland J i wsp. (red.) Psycho-Oncology, Oxford University Press, Oxford 2010; 90-97.

32. Hay JL, McCaul KD, Magnan RE. Does worry about breast cancer predict screening behaviours? A meta-analysis of the prospective evidence. Prev. Med. 2006, 42: 401:408.

33. Siahpush M, Singh GK. Social demographic variants in breast cancer screening behavior among Australian Women. Prev Med 2002; 35: 174-180.

34. BlackWC, Nease RF, Tosteson AN. Perceptions of breast cancer risk and screening effectiveness in women younger than 50 years of age. J. Natl. Cancer Inst. 1995; 87: 720-731.

35. de Walden-Gałuszko K, Psychoonkologia w praktyce klinicznej. Warszawa, Wydawnictwo Lekarskie PZWL; 2011, 49-58. 